\title{
Dynamics of ovarian maturation during the reproductive cycle of Metynnis maculatus, a reservoir invasive fish species (Teleostei: Characiformes)
}

\author{
Thiago Scremin Boscolo Pereira ${ }^{1}$, Renata Guimarães Moreira ${ }^{2}$ \\ and Sergio Ricardo Batlouni ${ }^{1}$
}

In this study, we evaluated the dynamics of ovarian maturation and the spawning processes during the reproductive cycle of Metynnis maculatus. Adult females $(\mathrm{n}=36)$ were collected bimonthly between April 2010 and March 2011. The mean gonadosomatic index (GSI) was determined, ovarian and blood samples were submitted for morphometric evaluation and the steroid plasma concentration was determined by ELISA. This species demonstrated asynchronous ovarian development with multiple spawns. This study revealed that, although defined as a multiple spawning species, the ovaries of M. maculatus have a pattern of development with a predominance of vitellogenesis between April and August and have an intensification in spawning in September; in October, a drop in the mean GSI values occurred, and the highest frequencies of post-ovulatory follicles (POFs) were observed. We observed a positive correlation between the POF and the levels of $17 \alpha$-hydroxyprogesterone. Metynnis maculatus has the potential to be used as a source of pituitary tissue for the preparation of crude extracts for hormonal induction; the theoretical period for use is from September to December, but specific studies to determine the feasibility of this approach must be conducted.

Neste estudo, avaliamos a dinâmica da maturação ovariana a desova durante o ciclo reprodutivo de Metynnis maculatus. Fêmeas adultas $(n=36)$ foram coletadas bimestralmente entre abril de 2010 e março de 2011. O índice gonadossomático (IGS) foi calculado e amostras de ovário e de sangue foram submetidas à avaliação morfométrica e das concentrações plasmáticas dos esteroides por ELISA, respectivamente. A espécie apresenta desenvolvimento ovariano assincrônico, com múltiplas desovas. Neste estudo revelamos que mesmo sendo de desova parcelada, os ovários do M. maculatus mostraram um padrão de desenvolvimento com predomínio de atividade vitelogênica entre abril a agosto e intensificação da desova em setembro. Em outubro houve uma diminuição nos valores médios de IGS, bem como registramos as maiores frequências de folículos pós-ovulatórios (FPOs). Observamos uma correlação positiva entre a frequência de FPOs e a concentração plasmática de $17 \alpha$-OHP. O $M$. maculatus tem potencial para ser usado como fonte para uso de hipófise para preparo de extrato bruto para indução hormonal, sendo o período teórico para coleta de hipófises de setembro a outubro, mas estudos específicos para esta finalidade ainda precisam ser desenvolvidos.

Key words: Multiple spawns, Oocyte development, Spawning season, Steroid levels.

\section{Introduction}

An environmental problem that influences aquaculture is the introduction of invasive species (Clavero \& GarcíaBerthou, 2005). In Brazil, especially in lakes formed by hydroelectric dams, many fish species are introduced, proliferate rapidly and displace native species (Agostinho et al., 2008; Moretto et al., 2008; Barros et al., 2012).
These areas are usually lotic environments formed by dams. Invasive species become established because they are successful in adjusting to freshwater environments that are modified or degraded by dams (Poff et al., 2007). Therefore, the spread of invasive species in lakes formed by dams is an environmental problem. However, little is known about the reproductive biology of these species in areas where they are introduced.

\footnotetext{
${ }^{1}$ Universidade Estadual Paulista "Júlio de Mesquita Filho", Centro de Aquicultura (CAUNESP), Via de Acesso Prof. Paulo Donato Castelane, s/n. 14884-900 Jaboticabal, SP, Brazil. (TSBP) thiago.scremin@gmail.com; (SRB) batlouni@caunesp.unesp.br

${ }^{2}$ Instituto de Biociências, Universidade de São Paulo. Rua do Matão, Trav. 14, n 321, 05508-090, São Paulo, SP, Brazil. renatagm@ib.usp.br
} 
Invasive species are generally small- to mediumsized, e.g., Cichla spp., Plagioscion squamosissimus, and Metynnis maculatus (Langeani et al., 2005, 2007); such species are often multiple spawning fish that spawn throughout the year (Souza et al., 2008; Vieira et al., 2009) without the need for migration. In some locations, introduced species become the main source of fish (Lima et al., 2010). Some species are not directly utilised for consumption due to their small size; however, these species have the potential to provide aquaculture sub-products such as fish meal and fish oil (Tacon \& Metian, 2008) and can be used as a pituitary source for the hormonal induction of reproduction in other species (Von Ihering, 1937). For this last purpose, it is necessary to know the appropriate time to collect pituitary glands, which is usually during the spawning season when pituitary LH levels are high (Mylonas et al., 2010).

Among invasive fish species, the characid M. maculatus deserves special attention. It is a small (approximately 18 $\mathrm{cm}$ ), herbivorous fish that is endemic to South America and native to the Paraguay and Amazon Basins (Kullander, 2003). It has been introduced into and is becoming invasive in South America (Langeani et al., 2007), especially in lakes and river branches in Southeast Brazil where it is very well acclimatised. It is the most frequently caught species in some regions (Langeani et al., 2005; Gomes et al., 2008); however, this fish is not used for human consumption. Due to its peculiar colour (silvery with numerous black spots on the body and red ventral fins), size and rounded shape, M. maculatus has great potential as an ornamental fish.

Given the importance of M. maculatus and the high occurrence of this species in fish landings, the aim of this study was to evaluate the characteristics of its reproductive cycle and spawning season. We considered the dynamics of ovarian maturation and the characteristics (duration and intensity) of the vitellogenic and spawning processes. In addition, we tested for a correlation between these values and the annual levels of the gonadal steroids $17 \beta$-estradiol $\left(\mathrm{E}_{2}\right)$ and $17 \alpha$-hydroxyprogesterone (17 $\alpha$-OHP).

\section{Materials and Methods}

Sample collection. Adult M. maculatus females $(\mathrm{n}=36)$ were collected bimonthly at a hydroelectric reservoir in Nova Avanhandava, São Paulo, Brazil ( $\left.21^{\circ} 07^{\prime} \mathrm{S} 50^{\circ} 17^{\prime} \mathrm{W}\right)$ between April 2010 and March 2011. The fish were captured using gillnets that were placed in the morning and removed late in the afternoon (10 hour exposure) at artisanal fisheries. Total length $(\mathrm{cm})$ and total body weight $(\mathrm{g})$ were recorded for each animal (Table 1). Some specimens were deposited in the Fish Collection of the Department of Zoology and Botany of the São Paulo State University (UNESP), São José do Rio Preto, Brazil.
Table 1. Biometrical parameters of female Metynnis maculatus during different time periods (mean \pm S.E.M).

\begin{tabular}{|c|c|c|c|}
\hline \multirow[b]{2}{*}{ Periods } & \multicolumn{2}{|c|}{ Variables } & \multirow[b]{2}{*}{$\mathrm{n}$} \\
\hline & Total length $(\mathrm{cm})$ & Total weight (g) & \\
\hline April 2010 & $15.16 \pm 0.40$ & $108.59 \pm 5.58$ & 06 \\
\hline June 2010 & $14.32 \pm 0.41$ & $83.19 \pm 10.77$ & 05 \\
\hline August 2010 & $15.50 \pm 0.50$ & $97.59 \pm 9.92$ & 08 \\
\hline October 2010 & $15.98 \pm 0.16$ & $121.56 \pm 4.31$ & 10 \\
\hline December 2010 & $15.95 \pm 0.25$ & $122.13 \pm 0.34$ & 02 \\
\hline February 2011 & $16.00 \pm 0.45$ & $142.18 \pm 20.40$ & 05 \\
\hline
\end{tabular}

Sample processing and histology. Fish were euthanised with a lethal dose of benzocaine ( $\left.28 \mathrm{mg} \mathrm{L}^{-1}\right)$ so that their gonads could be collected. The ovaries were removed and weighed to calculate the gonadosomatic index (GSI), which is the percentage of total body weight represented by the ovaries. For histological evaluation, ovarian samples (cranial, middle and caudal regions) were collected, fixed in Bouin solution and subjected to routine histological procedures. The fixed material was embedded in Historesin (Historesin Plus, Leica, Heidelberg, Germany), cut into $2 \mu \mathrm{m}$ thick sections and stained with haematoxylin-fluoxin.

Histomorphometric analyses. Morphometric analyses were performed on the ovary sections with ovarian lamellae that contained oocytes at various stages of development. The average diameter of 20 oocytes (in the cranial, middle, or caudal regions) at each stage of development was measured using an Olympus BX41 microscope system (4x magnification) with an Olympus DP11 capture apparatus (with measurements performed using Image-Pro Plus Version 4.1.0.0 software). Post-ovulatory follicles (POFs) were shapeless; therefore, the average diameter was not calculated.

Volume density. Volume density was determined using light microscopy and a 320-intersection grid. Three fields from each region of the ovary (cranial, middle, and caudal) ( 9 fields total) were randomly selected, giving a total of 2.880 points scored for each animal at $4 \mathrm{x}$ magnification. For this analysis, the method of Criscuolo-Urbinati et al. (2012) was used with certain modifications. Points were classified as one of the following: pre-vitellogenic (PV), cortical alveoli (CA), early vitellogenic with incomplete vitellogenesis and cytoplasm not filled with yolk (EV), final vitellogenic with cytoplasm filled with yolk (FV), atretic (AT), post ovulatory follicles (POF), and interstitial tissue (IT). Artefacts were rarely observed and were not considered in the total number of points used to obtain the percentages. The percentage of each ovarian component was calculated for four females (randomly selected) for each period; this measurement was calculated for only two females in December due to the small number of animals collected as a result of flooding. 
Blood sampling and steroids assays. The animals were anesthetised with benzocaine ( $\left.9 \mathrm{mg} \mathrm{L}^{-1}\right)$ for blood sampling. Blood was collected by puncturing the caudal vein with heparinised syringes (Liquemine, Roche, Rio de Janeiro, RJ, Brazil) and needles. Blood was centrifuged at 1300 $\mathrm{g}$ for 10 minutes. The plasma was separated into aliquots and frozen at $-80^{\circ} \mathrm{C}$ for the subsequent $17 \beta$-estradiol $\left(\mathrm{E}_{2}\right)$ and $17 \alpha$-hydroxyprogesterone (17 $\alpha$-OHP) assays. The plasma steroid level was measured by ELISA (Enzyme Linked Immunosorbent Assay) ( $\mathrm{E}_{2}$ and $17 \alpha-\mathrm{OHP}$ : Interteck, Virginia, USA). Plasma samples were run in duplicate with an acceptable limit of $\leq 20.0$ for the intra-assay coefficients of variation (Brown et al., 2004). Absorbance measurements were collected using a microplate reader (Molecular Devices, CA, USA). Specimens that were sampled between February and April 2010 were not used for steroid analysis because the animals remained in the nets for long periods. The difficulty of removing them from the nets would certainly alter the plasma steroid data; therefore, we decided to exclude these animals from the steroid analysis.

Data analysis. Data normality was checked using the Cramervon Mises test. Homoscedasticity was checked with the $F_{\max }$ test. The GSI, volume density and plasma steroid level of the oocytes were analysed by comparing different periods with a one-way analysis of variance (ANOVA). The Tukey test was used in post hoc analyses. Pearson's test, which is better suited for normal distribution data, was used to test for correlations. A threshold of $P \leq 0.05$ was set to infer statistical significance. All statistical analyses were based on Zar (1999).

Permission for fish collection. The sampling of fish in the wild was approved by the Environment Ministry-Chico Mendes Institute for Biodiversity Conservation, Brazil (Protocol number 25042-1).

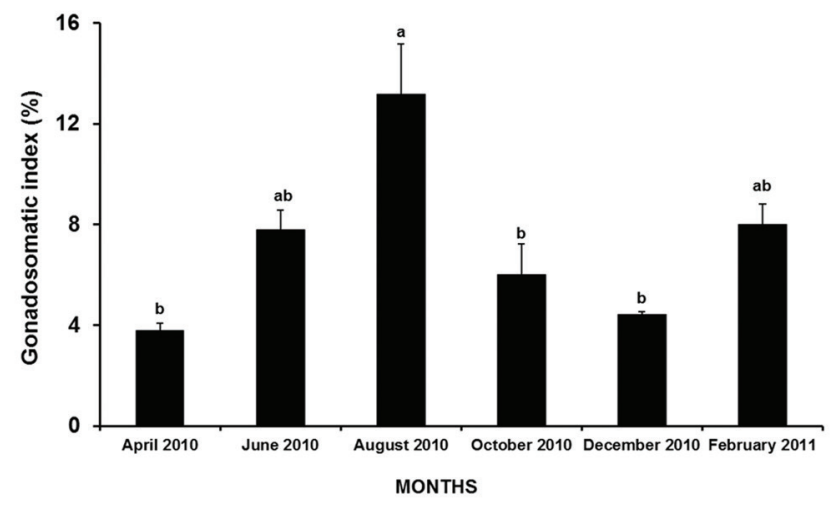

Fig. 1. Mean $( \pm$ S.E.M) bimonthly variations of the gonadosomatic index in Metynnis maculatus females $(\mathrm{n}=36)$. The different letters indicate significant differences among months. (ANOVA, Tukey test, $\mathrm{P}<0.05$ ).

\section{Results}

\section{GSI}

We observed a gradual increase in the mean GSI values between April 2010 (3.79 $\pm 0.36 \%)$ and August 2010; these values peaked in August 2010 (13.18 $\pm 1.99 \%)$. Values decreased sharply in October $2010(6.02 \pm 1.15 \%)$ and held steady until February 2011 (7.99 $\pm 0.83 \%)$ (one-way ANOVA: $\mathrm{F}=5.71, \mathrm{P}=0.0009, \mathrm{n}=36$, Fig. 1).

\section{Histomorphometrical evaluation of the ovaries}

Oocyte types. The following oocyte types were found in $M$. maculatus ovaries: PV, CA, AT, EV, FV, and POF (Table 2 and Fig. 2a-f). The early vitellogenic phase was characterised by the predominance of large cortical alveoli vesicles (Fig. 2c). These vesicles were gradually replaced by protein yolk granules concomitantly with vitellogenic progression (Fig. 2d).

Table 2. Histological descriptions and oocyte diameters during different developmental stages.

\begin{tabular}{|c|c|c|}
\hline Oocyte development stages & $\begin{array}{l}\text { Diameter }(\mu \mathrm{m}) \\
(\text { Mean } \pm \text { S.E.M) }\end{array}$ & Histological appearance \\
\hline Previtellogenic (PV) & $126.71 \pm 7.96$ & $\begin{array}{l}\text { The nucleus was large and centrally positioned with numerous nucleoli. The cytoplasm } \\
\text { was intensely basophilic. }\end{array}$ \\
\hline Cortical alveoli (CA) & $304.12 \pm 15.97$ & $\begin{array}{l}\text { The nucleus was large and slightly stained with numerous nucleoli. The cytoplasm contained } \\
\text { cortical alveoli. }\end{array}$ \\
\hline Early vitellogenic (EV) & $487.49 \pm 35.62$ & $\begin{array}{l}\text { The nucleus remained centrally positioned and had an irregular shape. A large number of } \\
\text { cortical alveoli vesicles were observed. }\end{array}$ \\
\hline Final vitellogenic (FV) & $1038.96 \pm 50.20$ & $\begin{array}{l}\text { The nucleus remained centrally positioned. The predominance of cortical alveoli vesicles } \\
\text { was no longer observed. Oocytes were at their maximum size and were filled with protein } \\
\text { yolk granules. }\end{array}$ \\
\hline Post-ovulatory follicles (POF) & Not measured & $\begin{array}{l}\text { Follicles had extensive border folding; follicular cells undergoing hypertrophy were visible } \\
\text { in some oocytes. }\end{array}$ \\
\hline Atretic (AT) & $617.65 \pm 46.12$ & $\begin{array}{l}\text { Atretic oocytes were observed during the entire oocyte development process. Vitellogenic } \\
\text { atretic oocytes often had broken or absent nuclei, fragmentation of the zone radiata and } \\
\text { irregular yolk distribution. }\end{array}$ \\
\hline
\end{tabular}




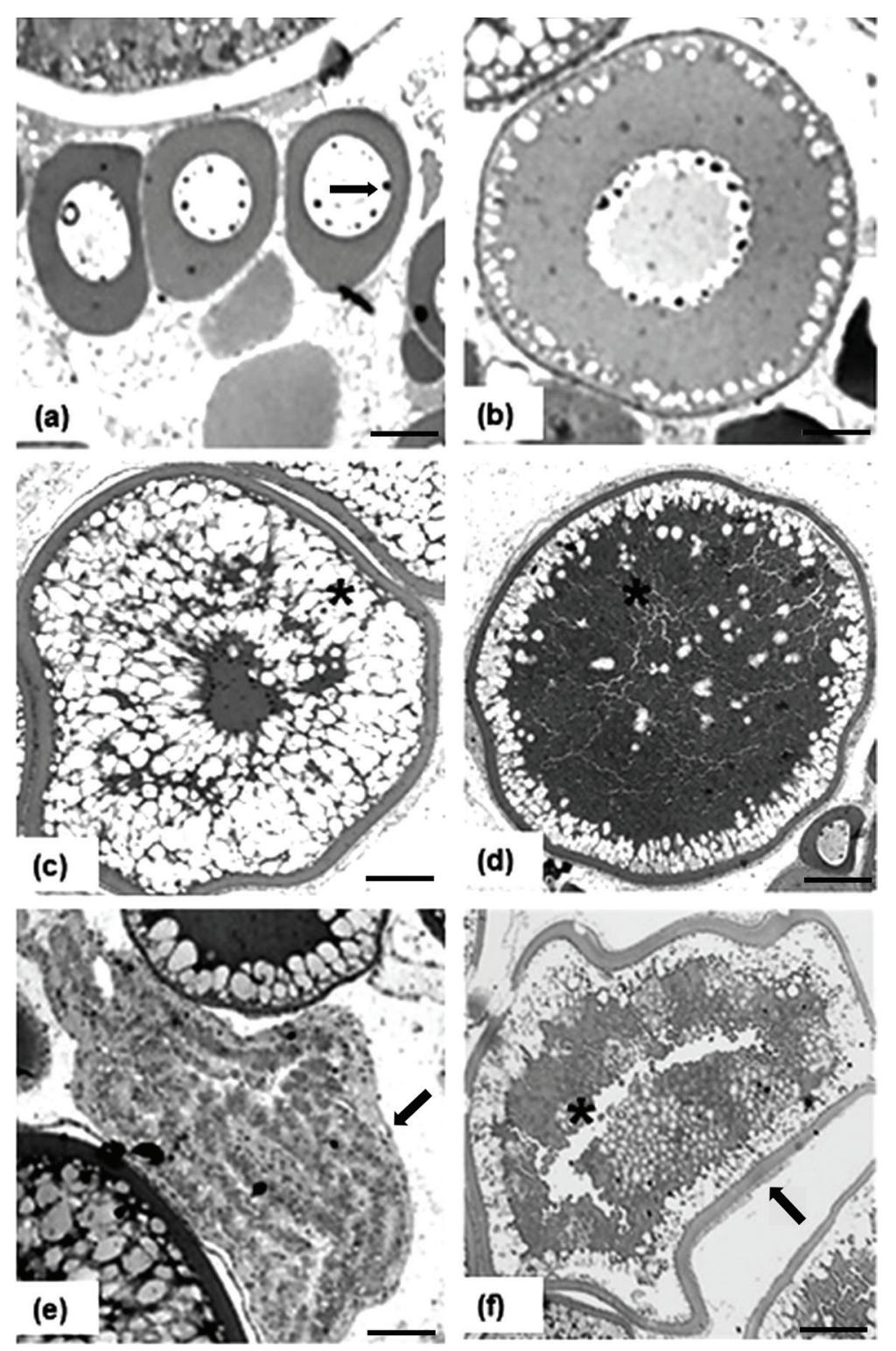

Fig. 2. Photomicrographs of different oocyte types observed during the Metynnis maculatus reproductive cycle. (a) Previtellogenic oocytes showing multiple nucleolus (arrow), (b) Cortical alveoli oocyte; (c) Early vitellogenic oocyte with cytoplasm filled mostly with cortical alveoli (asterisk); (d) Final vitellogenic oocyte with cytoplasm completely filled with protein yolk granules (asterisk); (e) Post ovulatory follicles with numerous border folding (arrow), (f) Atretic oocytes with fragmented vitelline membrane (arrow) and a change in the appearance of the cytoplasm (asterisk). Hematoxylin-floxin. Scale bar $=100 \mu \mathrm{M}$..

Volume density. We observed POFs throughout the year; however, there was a peak in October $2010(8.86 \pm 2.31 \%)$ (characterising the peak of breeding season). The value decreased by approximately $300 \%$ in December $2010(3.31 \pm$ $1.39 \%)$ and was close to zero in February $2011(0.54 \pm 0.32 \%)$ (one-way ANOVA: $\mathrm{F}=5.81, \mathrm{P}<0.0001, \mathrm{n}=4-2$, Fig. 3). FV were also observed throughout the year; however, a slight and gradual decrease was observed close to the breeding season from June $2010(71.31 \pm 5.47 \%)$ to October 2010 (48.87 \pm $5.19 \%$ ) (one-way ANOVA: $\mathrm{F}=2.34, \mathrm{P}=0.04, \mathrm{n}=4-2$, Fig. 3 ).
The EV profile was irregular during the reproductive cycle. We observed the lowest percentages in June 2010 $(11.23 \pm 3.19 \%)$ and February $2011(13.30 \pm 3.89 \%)$. Although not significant, a nearly three-fold increase was observed between June $2010(11.23 \pm 3.19 \%)$ and August 2010 (this was the most intense vitellogenic period and coincided with the GSI peak). Following this time period, the EV profile remained stable until December 2010 (27.78 $\pm 9.18 \%$ ); this time period coincided with the end of the breeding season. A marked decrease was observed between 


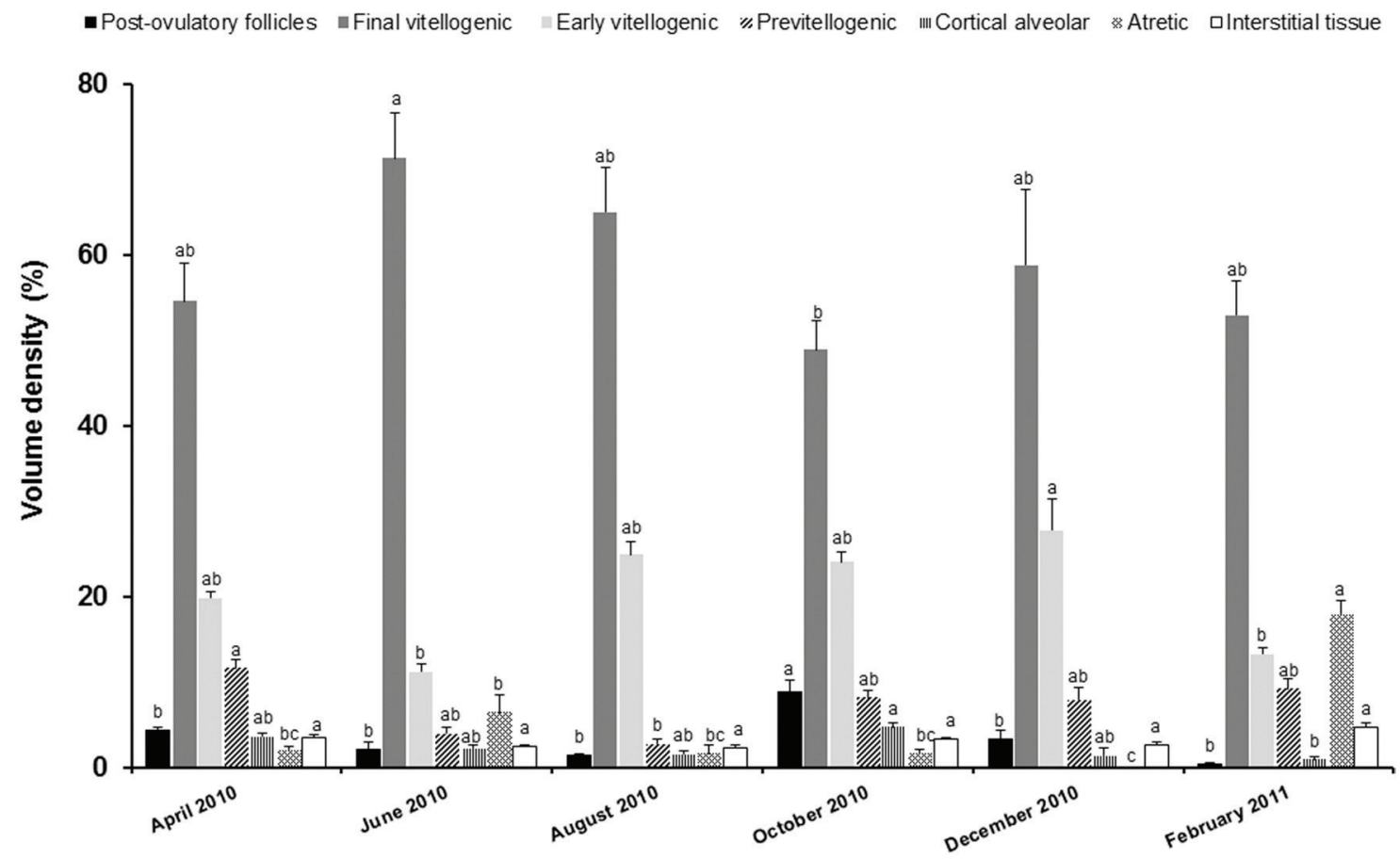

Fig. 3. Mean percentages ( \pm S.E.M) of different oocyte types from Metynnis maculatus females during the ovarian maturation cycle. Different letters indicate significant differences among the same type of oocytes among months (ANOVA, Tukey test, $\mathrm{P}<0.05$ ).

December $2010(27.78 \pm 9.18 \%)$ and February 2011 (13.30 $\pm 3.89 \%$ ); this time period coincided with the greatest AT frequency and characterised the end of breeding season (oneway ANOVA: $\mathrm{F}=2.41, \mathrm{P}=0.04, \mathrm{n}=4-2$, Fig. 3 ).

PV oocytes were observed during the entire experimental period and exhibited an irregular profile (Fig. 3). The volume density of PV decreased markedly between April $2010(11.68 \pm 2.08 \%)$ and August $2010(2.85 \pm 0.80)$, which is the period of most intense vitellogenesis. Although not significant, the values increased by nearly $400 \%$ between August 2010 and October 2010 (during the peak of the vitellogenic period) and remained stable in October 2010 $(8.25 \pm 1.37 \%)$, December $2010(7.99 \pm 2.33 \%)$ and February $2011(9.27 \pm 3.64 \%)$ (one-way ANOVA: $\mathrm{F}=2.64$, $\mathrm{P}=0.02, \mathrm{n}=4-2$, Fig. 3).

The CA profiles were regular and stable during the majority of the reproductive cycle. Between August 2010 (1.62 \pm 0.79$)$ and October $2010(4.80 \pm 1.73)$, the CA profiles increased more than $200 \%$. This result confirms that August through October is the peak of the vitellogenic period. A gradual decrease was observed between October 2010 (4.80 \pm 1.73$)$ and February $2011(1.03 \pm 0.48)$; this decrease in the CA profile coincided with the end of the breeding season and the highest volume density of AT (one-way ANOVA: $\mathrm{F}=2.63$, P $=0.02, \mathrm{n}=4-2$, Fig. 3).
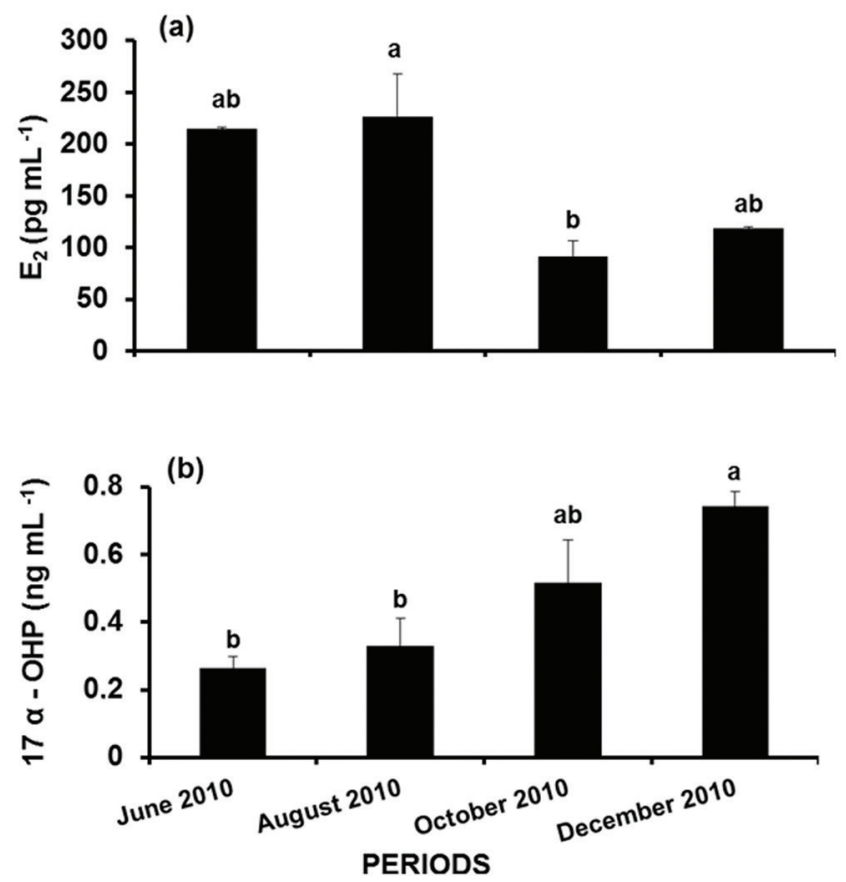

Fig. 4. (a) Mean ( \pm S.E.M) bimonthly plasma concentrations of $E_{2}$ in Metynnis maculatus females $(\mathrm{n}=20)$. Different letters indicate significant differences among months (ANOVA, Tukey test, $\mathrm{P}<$ $0.05)$. (b) Mean ( \pm S.E.M) bimonthly plasma $17 \alpha-$ OHP concentrations $(n=20)$. Different letters indicate significant differences among months. (ANOVA, Tukey test, $\mathrm{P}<0.05$ ). 

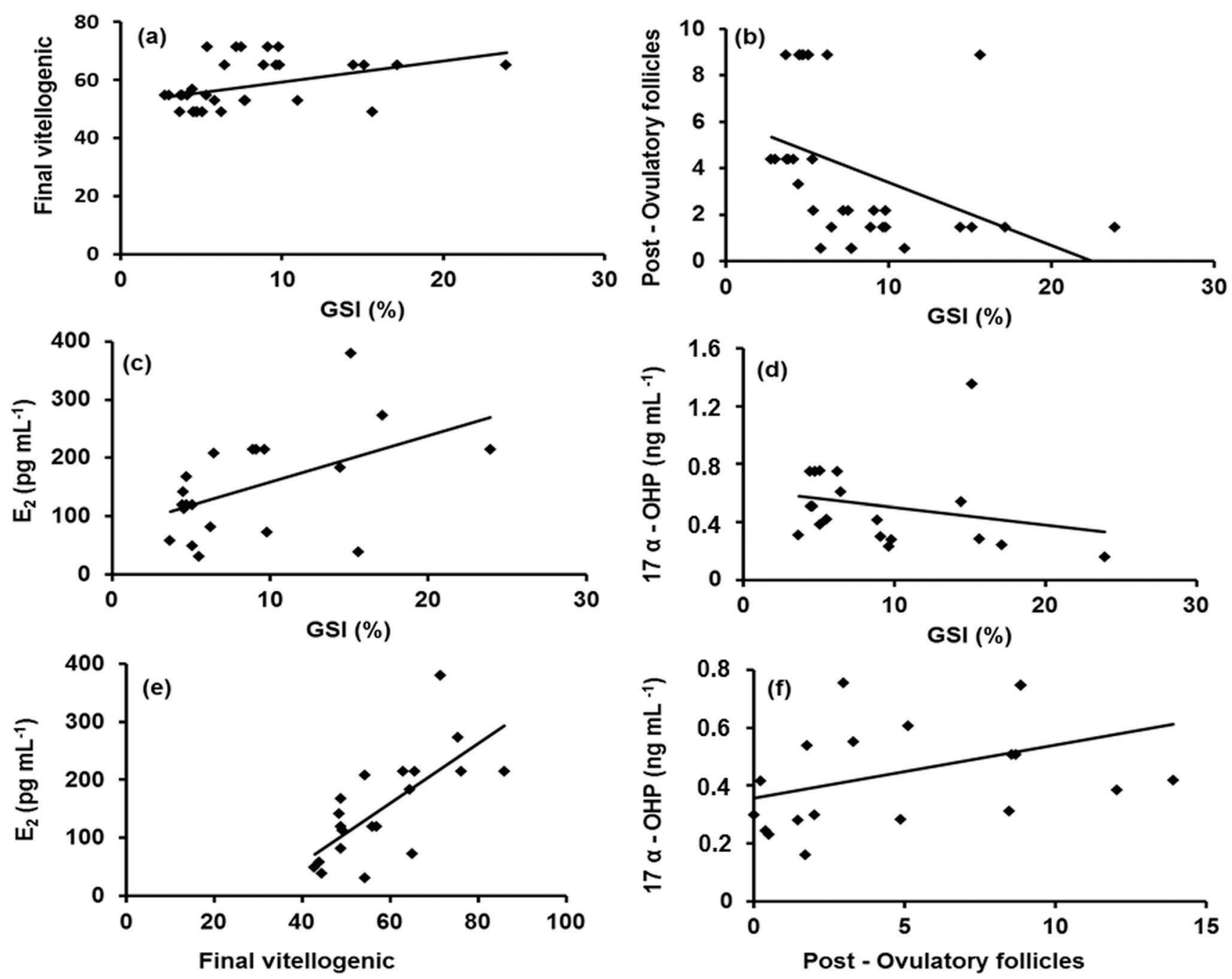

Fig. 5. (a) Pearson correlation between the volume density of final vitellogenic oocytes and the gonadosomatic index (GSI) (\%) during the reproductive cycle of Metynnis maculatus females $(\mathrm{n}=36)$. (b) Pearson correlation between the volume density of post-ovulatory follicles and the GSI $(\%)(\mathrm{n}=36)$. (c) Pearson correlation between the $\mathrm{E}_{2}$ plasma levels and the GSI $(\%)(n=20)$. (d) Pearson correlation between the 17 $\alpha$-OHP plasma levels and the GSI $(\%)(n=20)$. (e) Pearson correlation between the $E_{2}$ plasma levels and the volume density of final vitellogenic oocytes $(n=20)$. (f) Pearson correlation between the $17 \alpha$-OHP plasma levels and the volume density of the post-ovulatory follicles $(n=20)$. The continuous line indicates that the difference is statistically significant (Pearson's test, $\mathrm{P}<0.05$ ).

The highest AT densities were found at the end of the breeding season, in February 2011 (18.02 $\pm 3.02 \%)$. The AT densities increased by more than $1000 \%$ from December $2010(0 \%)$ (one-way ANOVA: $\mathrm{F}=11.66, \mathrm{P}<0.0001, \mathrm{n}=$ 4-2, Fig. 3). The percentage of IT remained stable (3-5\%) during the entire experimental period. However, the highest IT values were found in February (4.82 $\pm 1.05 \%$ ), and a peak was observed for AT (one-way ANOVA: $\mathrm{F}=1.88, \mathrm{P}=0.10$, $\mathrm{n}=4-2$, Fig. 3).

Steroid hormones. The $\mathrm{E}_{2}$ plasma levels were higher in August than in October ( $P=0.021$, Fig. 4a). The 17 $\alpha$-OHP plasma levels presented with inverse profiles when compared to $\mathrm{E}_{2}$. Lower $17 \alpha$-OHP plasma levels were observed in June and August compared to December $(P=0.009$, Fig. 4b).
Correlations between variables. We observed a positive correlation between the GSI and the FV oocytes (Pearson correlation: $\mathrm{r}=0.52, \mathrm{P}=0.001, \mathrm{n}=36$, Fig. 5a) and a negative correlation between the GSI and the POF (Pearson correlation: $r=-0.50, P=0.002, n=36$, Fig. $5 b$ ). The plasma $\mathrm{E}_{2}$ levels were positively correlated with GSI (Pearson correlation: $\mathrm{r}=0.52, \mathrm{P}=0.01, \mathrm{n}=20$, Fig. $5 \mathrm{c}$ ) and with the volume density of FV (Pearson correlation: $\mathrm{r}=0.70, \mathrm{P}$ $=0.0005, \mathrm{n}=20$, Fig. 5e). There was a positive correlation between the 17 $\alpha$-OHP plasma levels and the volume density of POF (Pearson correlation: $r=0.50, P=0.03, n=20$, Fig. $5 \mathrm{f}$ ) and a negative correlation between the $17 \alpha$-OHP plasma levels and the GSI (Pearson correlation: $\mathrm{r}=-0.61, \mathrm{P}=0.005$, $\mathrm{n}=20$, Fig. $5 \mathrm{~d})$. 


\section{Discussion}

Metynnis maculatus can be classified as a tropical fish that exhibits asynchronous oocyte development with multiple spawning periods; all stages of oocyte development and POFs were observed throughout the reproductive cycle. In this context, $M$. maculatus has the necessary features to classify it as a parcelled spawner fish. According to Lubzens et al. (2010), synchronous fish have two or more distinct populations of oocytes presenting simultaneously and ovulate either once per season or undergo multiple ovulations over a period of few days or weeks within the spawning season. Using this definition, we can classify M. maculatus as a multiple spawner fish, as POFs and CA are detected throughout the year. The volume density of POFs suggests that there are more than two distinct populations of oocytes present simultaneously. The CA suggests that multiple ovulations occur over a period of weeks within the spawning season.

In support of our results, most descriptions of tropical multiple spawner fish report a long breeding period with a period where spawning peaks. As with M. maculatus, these species with a GSI peak and/or a higher percentage of spawned/ mature females often occur during the spring-summer season, especially around October (Barbieri, 1995; Lamas \& Godinho, 1996; Schifino et al., 1998; Ribeiro et al., 2007). In this study, we observed (via the analysis of post-ovulatory follicles and the distribution of mature oocytes throughout the year) that M. maculatus females have a prolonged spawning period and spawn almost the entire the year (characterised by parcelled spawning) (Lamas \& Godinho, 1996; Tyler \& Sumpter, 1996; Vazzoler, 1996; Murua \& Saborido-Rey, 2003; Lubzens et al., 2010; Mylonas et al., 2010; Ganias, 2012).

In South American countries, carp pituitary extracts are the main source of hormones for the strip-spawning induction of rheophilic fish (Dias et al., 2012; Criscuolo-Urbinati et al., 2012; Felizardo et al., 2012; Hainfellner et al., 2012a, 2012b; Honji et al., 2012; Nogueira et al., 2012; Weber et al., 2012). The native species of the South American continent are not exploited for this purpose, although it is an interesting way to add value to local fisheries and aquaculture by-products. In this work, we report for the first time the relationship between the stages of the reproductive cycle (vitellogenesis and the spawning season) and the seasonal sex steroid ( $\mathrm{E}_{2}$ and $17 \alpha$-OHP) plasma concentrations in multiple spawner tropical fish $M$. maculatus. We determined that $M$. maculatus has the potential to be used as a source of pituitary extract based on its marked reproductive seasonality, which is similar to total spawner fish (Von Ihering, 1937; Breton et al., 1998; Perdikaris et al., 2007). Data concerning LH levels in South American tropical fish in the wild are absent, these data on the plasma and pituitary LH levels in a few parcelled (Aizen et al., 2012) and total spawners (Breton et al., 1998) studied in captivity confirm that the peak of pituitary and plasma LH can occur prior to spawning, during spawning or right after spawning; the particulars are species-dependent. We did not measure the LH plasma or pituitary levels in this study. We did observe that the spawning peak was in September, when the $17 \alpha-\mathrm{OHP}$ plasma levels started to increase. These levels were highest in December (at the end of the breeding season). 17 $\alpha-\mathrm{OHP}$ is the main precursor of $17 \alpha, 20 \beta$-dihydroxy-4-pregnen-3one (17 $\alpha, 20 \beta$-DHP), which is the most potent hormone that induces oocyte maturation and ovulation in teleosts (Nagahama \& Yamashita, 2008). In trout, the highest LH levels are found 15 days after spawning (Breton et al., 1998). Therefore, we suggest that M. maculatus pituitaries with high LH levels could be obtained from September to December, but specific studies for this purpose must be undertaken.

Considering the POFs, it is possible that those described in this study belonged to females that were collected shortly after spawning. The collected POFs resembled those of Pseudoplatystoma fasciatum (a total spawner tropical fish) at 12 hours post-fertilisation (Romagosa et al., 2005). However, further studies are necessary to confirm the morphology of M. maculatus POFs following the predicted periods after the induction of spawning (for review see Ganias, 2012). The literature on follicle aging in South American tropical fish is limited. It is known that the age of the follicles is species specific and that their degeneration may last from a few hours to many months (Ganias, 2012). Whether this species exhibits daily spawning synchronicity should be studied, and the fraction of spawners within a given number of females needs to be determined. Such data are needed to elucidate the reproductive strategy of this species and to support attempts to establish a protocol for obtaining pituitaries for hormonal induction purposes.

We must highlight that the "hypophysation" technique, which involves the use of pituitary extract to induce spawning in fish, and was established in Brazil in the late 1930s (Von Ihering, 1937; Fontenele, 1955). The idea of collecting pituitaries from mature fish was also originated in Brazil (Fontenelle, 1955). Today (almost 80 years after the development of this methodology), we still face problems with hypophysation and the exploitation of migratory species (Criscuolo-Urbinati et al., 2012). Conversely, the use of pituitary extract has been replaced by safer and more efficient synthetic products for many other fish species (Mylonas et al., 2010). However, the use of these synthetic products (mainly GnRH analogues) has been not effective for South American tropical fish species; although the females ovulate, the viability rates of the embryos are very low or close to zero (Acuña \& Rangel, 2009; Paulino et al., 2011). Although further studies on the use synthetic hormones are needed, we must also consider the use of pituitary extract as a necessity for producing South American tropical species. 
We observed an association between the $\mathrm{E}_{2}$ plasma levels and vitellogenesis (which occurs from August to October). The following two distinct phases of M. maculatus vitellogenesis occur: the first phase is characterised by the accumulation of cortical alveoli vesicles, and the second phase is marked by the replacement of the cortical alveoli vesicles by a protein yolk that occupies almost the entire cytoplasm in FV. Our findings were similar to those described by França et al. (2010) for the freshwater South American fish Gymnotus sylvius. In accordance with the previous report, the cortical alveoli vesicles in M. maculatus occupied the entire cytoplasm of the early vitellogenic oocytes while being restricted to the oocyte cortex in final stages of oocyte development. In this context, we must emphasise that there was a slight advance in the vitellogenic period (April to August) and in the spawning period (August to December) in M. maculatus compared with total spawning species (Brito \& Bazzoli, 2003; Costa \& Mateus, 2009; Honji et al., 2009; Hainfellner et al., 2012b). The vitellogenic period and the spawning period typically occur between April and October and between November and February, respectively, in total spawning species. In M. maculatus, this slight advance in reproductive activities may have an ecological explanation.

We observed that M. maculatus also has a period of very low reproductive activity between December and February (increased volume density of AT). During this period, the ovaries have an intense period of oocyte resorption (a higher percentage of atretic oocytes) and rearrangement that is characterised by a thickening of the interstitial tissue (Miranda et al., 1999; Leonardo et al., 2006; Lubzens et al., 2010); this is similar to the more widely studied total spawner fish (Miranda et al., 1999; Leonardo et al., 2006; Hainfellner et al., 2012a). Therefore, using morphometric analysis we determined that the composition of the ovary is not the same throughout the year. The frequencies of the different types of oocytes vary throughout the year according to the main functions of the ovary, which are vitellogenesis and ovulation.

This study revealed that, although this species is defined as a multiple spawning species, the ovaries of $M$. maculatus displayed a pattern of development very similar to tropical total spawner migratory fish. Vitellogenesis predominated during the autumn/winter period (Honji et al., 2009; Hainfellner et al., 2012b), and spawning intensified in the spring/summer period (Agostinho et al., 2004; Caneppele et al., 2009; Romagosa, 2010; Honji et al., 2011). The variation in the levels of the sex steroids $\mathrm{E}_{2}$ and $17 \alpha-\mathrm{OHP}$ that was observed during the reproductive cycle of $M$. maculatus was similar to those observed in tropical freshwater species with group synchronous ovarian development (Gazola et al., 1996; Arantes et al., 2010). This species does not spawn regularly throughout the year with the same intensity, as spawning peaks in spring or summer (mainly in spring). These findings are similar to those in other non-migratory tropical parcelled spawner fish that have been studied previously (Barbieri, 1995; Lamas \& Godinho, 1996; Schifino et al., 1998; Ribeiro et al., 2007). Therefore, the ideal theoretical period to obtain M. maculatus pituitary tissue for the preparation of extracts for hormonal induction is from September to December; specific studies are necessary for this purpose, as there are differences in spawned and not spawned females (Breton et al., 1998; Aizen et al., 2012). As an invasive species with a high frequency of capture in the fisheries of hydroelectric reservoirs, $M$. maculatus has the potential to be used as a source of pituitary extract for hormonal induction. Further experiments should be conducted to test the efficacy of the pituitary crude extract of this species, to establish appropriate doses, to determine the feasibility of obtaining this gland and to assess the possibility of the domestication of this species.

\section{Acknowledgments}

The authors thank Msc. Camila N. P. Boscolo (CAUNESP, Jaboticabal, Brazil) for technical support and for critical suggestions for this manuscript and Dr. Francisco Langeani for the identification of species. We also thank the NomuraBoscolo family for their support during data collection.

\section{Literature Cited}

Acuña, J .J. A. \& J. L. H. Rangel. 2009. Effects of hypophyseal extract of common carp and the analog of the GnRH on the final maturation oocyte and the spawning of cachama negra (Colossoma macropomum). Revista Científica, FCV-LUZ, XIX: 486-494.

Agostinho, A. A., L. C. Gomes, S. Veríssimo \& E. K. Okada. 2004. Flood regime, dam regulation and fish in the Upper Parana River: effects on assemblage attributes, reproduction and recruitment. Reviews in Fish Biology and Fisheries, 14: 11-19.

Agostinho, A. A., F. M. Pelicice \& L. C. Gomes. 2008. Dams and the fish fauna of the Neotropical region: impacts and management related to diversity and fisheries. Brazilian Journal of Biology, 4: 1119-1132.

Aizen, J., M. Kobayashi, I. Selicharova, Y. C. Sohn, G. Yoshizaki \& B. Levavi-Sivan. 2012. Steroidogenic response of carp ovaries to piscine FSH and LH depends on the reproductive phase. General and Comparative Endocrinology, 178: 28-36.

Arantes, F. P., H. B. Santos, E. Rizzo, Y. Sato \& N. Bazzoli. 2010. Profiles of sex steroids, fecundity, and spawning of the curimatã-pacu Prochilodus argenteus in the São Francisco River, downstream from the Três Marias Dam, Southeastern Brazil. Animal Reproduction Science, 118: 330-336.

Barbieri, G., 1995. Biologia populacional de Cyphocarax modesta (HENSEL, 1869) (Characiformes, Curimatidae) da represa do Lobo (Estado de São Paulo) II. Dinâmica da reprodução e influência de fatores abióticos. Boletim do Instituto de Pesca, 22: 57-62.

Barros, L. C., U. Santos, J. C. Zanuncio \& J. A. Dergam. 2012. Plagioscion squamosissimus (Sciaenidae) and Parachromis managuensis (Cichlidae): A threat to native fishes of the Doce river in Minas Gerais, Brazil. Plos One, 7: 39138.

Breton, B., M. Govoroun \& T. Mikolajczyk. 1998. GTH I and GTH II secretion profiles during the reproductive cycle in female rainbow trout: relationship with pituitary responsiveness to GnRH-A stimulation. General and Comparative Endocrinology, 111: 38-50. 
Brito, M. F. G. \& N. Bazzoli. 2003. Reproduction of the surubim catfish (Pisces, Pimelodidae) in the São Francisco River, Pirapora Region, Minas Gerais Brazil. Arquivo Brasileiro de Medicina Veterinária e Zootecnia, 55: 624-633.

Brown, J., S. E. Walker \& K. Steinmain. 2004. Endocrine manual for the reproductive assessment of domestic and non-domestics species. Conservation and Research Center, Smithsonian's National Zoological Park, Front Royal, Virginia-EUA.

Caneppele, D., R. M. Honji, A. W. S. Hilsdorf \& R. G. Moreira. 2009. Induced spawning of the Neotropical endangered species Steindachneridion parahybae (Siluriformes: Pimelodidae). Neotropical Ichthyology, 7: 759-762.

Clavero, M., García-Berthou E., 2005: Invasive species are a leading cause of animal extinctions. Trends in Ecology and Evolution, 20: 110.

Costa, R. M. R. \& L. A. F. Mateus. 2009. Reproductive biology of pacu Piaractus mesopotamicus (Holmberg, 1887) (Teleostei: Characidae) in the Cuiabá River Basin, Mato Grosso, Brazil. Neotropical Ichthyology, 7: 447-458.

Criscuolo-Urbinati, E., R. Y. Kuradomi, E. C. Urbinati \& S. R. Batlouni. 2012. The administration of exogenous prostaglandin may improve ovulation in pacu (Piaractus mesopotamicus). Theriogenology, 78: 2087-2094.

Dias, D. C., A. F. G. Leonardo, L. Tachibana, C. F. Correa, I. C. A. C. Bordon, E. Romagosa \& M. J. T. Ranzani-Paiva. 2012. Effect of incorporating probiotics into the diet of matrinxã (Brycon amazonicus) breeders. Journal of Applied Ichthyology, 28: $40-45$.

Fontenele, O. 1955. Injecting pituitary hypophyseal hormones into fish to induce spawning. The Progressive Fish-Culturist, 17: 71-75.

França, G. F., H. J. Grier \& I. Quagio-Grassiotto, 2010. A new vision of the origin and the oocyte development in the ostariophysi applied to Gymnotus sylvius (Teleostei, Gymnotiformes). Neotropical Ichthyology, 8: 787-804.

Felizardo, V. O., L. D. S. Murgas, E. S. Andrade, P. A. López, R. T. F. Freitas \& M. R. Ferreira. 2012. Effect of timing of hormonal induction on reproductive activity in lambari (Astyanax bimaculatus). Theriogenology, 77: 1570-1574.

Gazola, R., M. I. Borela, E. M. Donaldson, M. V. Val-Sella, N. Sukumasavin, F. Fava de-Moraes \& G. Bernardino. 1996. Plasma steroid and corticosteroid levels in female pacu Piaractus mesopotamicus, Teleostei-Characidae. Brazilian Journal of Medical and Biological Research, 29: 659-664.

Gomes, J. H. C., A. C. I. M. Dias \& C. C. Branco. 2008. Fish assemblage composition in three reservoirs in the State of Rio de Janeiro. Acta Limnologica Brasiliensia, 20: 373-380.

Ganias, K. 2012. Thirty years of using the postovulatory follicles method: overview, problems and alternatives. Fisheries Research, 117-118: 63-74.

Hainfellner, P., M. E. Munõz, T. G. de Souza, G. A. Freitas \& S. R. Batlouni. 2012a. Spawning failure in Brycon amazonicus may be associated with ovulation and not with final oocyte maturation. Arquivo Brasileiro de Medicina Veterinária e Zootecnia, 64: 515-517.

Hainfellner, P., T. G. Souza, R. G. Moreira, L. S. O. Nakaghi \& S. R. Batlouni. 2012b. Low estradiol levels, delayed vitellogenesis and reduced amounts of yolk are dysfunctions associated with the formation of low quality oocytes in Prochilodus lineatus (Teleostei: Characiformes). Neotropical Ichthyology, 10: 601-612.

Honji, R. M., A. M. Narcizo, M. I. Borella, E. Romagosa \& R. G. Moreira. 2009. Patterns of oocyte development in natural habitat and captive Salminus hilarii Valenciennes, 1850 (Teleostei: Characidae). Fish Physiology and Biochemistry, 35: 109-123.
Honji, R. M., P. H. Mello, B. C. Araújo, J. A. Rodrigues-Filho, A. W. S. Hilsdorf \& R. G. Moreira. 2011. Influence of spawning procedure on gametes fertilization success in Salminus hilarii Valenciennes, 1850 (Teleostei: Characidae): Implications for the conservation of this species. Neotropical Ichthyology, 9: 363-370.

Honji R. M., C. E. Tolussi, P. H. Mello, D. Caneppele \& R. G. Moreira. 2012. Embryonic development and larval stages of Steindachneridion parahybae (Siluriformes: Pimelodidae) implications for the conservation and rearing of this endangered Neotropical species. Neotropical Ichthyology, 10: 313-327.

Kullander, S. O. 2003. Family Cichlidae (Cichlids). Pp. 605-654. In: Reis, R. E., S. O. Kullander \& C. J. Ferraris Jr. (Eds.). Check list of the freshwater fishes of South and Central America. Edipucrs, Porto Alegre.

Lamas, I. R. \& A. L. Godinho. 1996. Reproduction in the piranha Serrassalmus spilopleura, a neotropical fish with an usual pattern of sexual maturity. Environmental Biology of Fishes, 45: 161-168.

Langeani, F., L. Casatti, H. S. Gameiro, A. B. Carmo \& D. C. RossaFeres. 2005. Riffle and pool fish communities in a large stream of southeastern Brazil. Neotropical Ichthyology, 3: 305-311.

Langeani, F., R. M. C. Castro, O. T. Oyakawa, O. A. Shibatta, C. S. Pavanelli \& L. Casatti. 2007. Diversidade da ictiofauna do Alto Rio Paraná: composição atual e perspectivas futuras. Biota Neotropica, 7: 181-197.

Leonardo, A. F. G., E. Romagosa, S. R. Batlouni \& M. I. Borella. 2006. Occurrence and significance of ovarian and follicular regression in cachara Pseudoplatystoma fasciatum (Linnaeus, 1766): a histology approach. Arquivo Brasileiro de Medicina Veterinária e Zootecnia, 58: 831-840.

Lima, P. F., O. A. Latini \& M. P. Júnior. 2010. How are the lakes? Environmental perception by fishermen and alien fish dispersal in Brazilian tropical lakes. Interciência, 35: 84-91.

Lubzens, E., G. Young, J. Bobe \& J. Cerdà. 2010. Oogenesis in teleosts: how fish eggs are formed. General and Comparative Endocrinology, 165: 367-389.

Miranda, A. C. L., N. Bazzoli, E. Rizzo \& Y. Sato. 1999. Ovarian follicular atresia in two teleost species: a histological and ultrastructural study. Tissue \& Cell, 31: 480-488.

Moretto, E. M., F. T. Marciano, M. R. Velludo, N. Fenerich-Verani, E. L. G. Espindola \& O. Rocha. 2008. The recent occurrence, establishment and potential impact of Geophagus proximus (Cichlidae: Perciformes) in the Tietê River reservoirs: an Amazonian fish species introduced in the Paraná Basin (Brazil). Biodiversity and Conservation, 17: 3013-3025.

Murua, H. \& F. Saborido-Rey. 2003. Female reproductive strategies of marine fish species of the North Atlantic. Journal of Northwest Atlantic Fishery Science, 33: 23-31.

Mylonas, C. C., A. Fostier \& S. Zanuy. 2010. Broodstock management and hormonal manipulations of fish reproduction. General and Comparative Endocrinology, 165: 516-534.

Nagahama, Y. \& M. Yamashita. 2008. Regulation of oocyte maturation in fish. Development, Growth \& Differentiation, 50: 195-219.

Nogueira, L. B., P. G. Azevedo, M. R. Canelhas, A. G. Bedore, J. M. Lopes \& H. P. Godinho. 2012. Induced spawning and early ontogeny in hatchery-reared catfish Zungaro jahu (Siluriformes: Pimelodidae). Neotropical Ichthyology, 10: 89-98.

Paulino, M. S., M. Sampaio, A. B. Miliorini, L. D. S. Murgas, F. S. M. Lima \& V. O. Felizardo. 2011. Desempenho reprodutivo do pacu, piracanjuba e curimba induzidos com extrato de buserelina. Boletim do Instituto de Pesca, 37: 39-45. 
Perdikaris, C., B. Levavi-Sivan, A. Chantzaropoulos, C. Nathanailides, E. Gouva \& I. Paschos. 2007. Pituitary collection from Gibel carp Carassius gibelio (Bloch 1782) in Lake Pamvotis (Greece): prospects for use in carp reproduction. The Israeli Journal of Aquaculture-Bamidgeh, 59: 162-167.

Poff, N. L., J. D. Olden, D. M. Merritt \& D. M. Pepin. 2007. Homogenization of regional river dynamics by dams and global biodiversity implications. Proceedings of the National Academy of Sciences, 104: 5732-5737.

Ribeiro, V. M. A., G. B. Santos \& N. Bazzoli. 2007. Reproductive biology of Steindachnerina insculpta (Fernandez-Yépez) (Teleostei, Curimatidae) in Furnas reservoir, Minas Gerais, Brazil. Revista Brasileira de Zoologia, 24: 71-76.

Romagosa, E., S. R. Batlouni, M. I. Borella \& A. F. G. Leonardo. 2005. Involução dos folículos pós-ovulatórios em Pseudoplatystoma fasciatum (Pisces, Teleostei). Boletim do Instituto de Pesca, 31: 129-135.

Romagosa, E. 2010. Reproductive status in females of the Brazilian catfish, Pseudoplatystoma fasciatum reared in cages. Journal of Applied Ichthyology, 26: 806-811.

Schifino, L. C., L. Cabral, C. B. Fialho \& J. R. Verani. 1998. Reproductive aspects of Cyphocharax voga (Hensel) from Custódias lagoon, Rio Grande do Sul, Brazil (Characiformes, Curimatidae). Revista Brasileira de Zoologia, 15: 767-773.

Souza, J. E., E. N. Fragoso-Moura, N. Fenerich-Verani, O. Rocha \& J. R. Verani. 2008. Population structure and reproductive biology of Cichla kelberi (Perciformes, Cichlidae) in Lobo Reservoir, Brazil. Neotropical Ichthyology, 6: 201-210.
Tacon, A. G. J. \& M. Metian. 2008. Global overview on the use of fish meal and fish oil in industrially compounded aquafeeds: trends and future prospects. Aquaculture 285: 146-158.

Tyler, C. R \& J. P. Sumpter. 1996. Oocyte growth and development in teleosts. Reviews in Fish Biology and Fisheries, 6: 287-318.

Vazzoler, A. E. 1996. Biologia da reprodução de peixes teleósteos: teoria e prática. Maringá, EDUEM.

Vieira, A. B. C., L. F. Salvador-Jr., R. M. C. Melo, G. B. Santos \& N. Bazzoli. 2009. Reproductive biology of the peacock bass Cichla piquiti (Perciformes: Cichlidae), an exotic species in a Neotropical reservoir. Neotropical Ichthyology, 7: 745-750.

Von Ihering, R. 1937. A method for inducing fish to spawn. The Progressive Fish-Culturist, 34: 15-16.

Weber, A. A., Y. Sato, J. E. Santos, E. Rizzo \& N. Bazzoli. 2012. Eggs ultrastructure and early development of Franciscodoras marmoratus (Pisces: Doradidae). Anatomia, Histologia, Embryologia, 41: 177-183.

Zar, J. H. 1999. Biostatistical Analysis, 4th edn. Upper Saddle River, NJ: Prentice Hall.

Submitted March 25, 2013

Accepted September 4, 2013 by Bernardo Baldisserotto

Published December 27, 2013 